\title{
Smallholding farmers' resilience towards economic and ecological disruption of oil palm plantations
}

\author{
Irham $^{1}$, Apri Andani ${ }^{2,3, *}$, Jamhari $^{1}$, Any Suryantini ${ }^{1}$ \\ ${ }^{1}$ Agribusiness Department, Faculty of Agriculture, Universitas Gadjah Mada, Yogyakarta, Indonesia \\ ${ }^{2}$ Postgraduate Student, Faculty of Agriculture, Universitas Gadjah Mada, Yogyakarta, Indonesia \\ ${ }^{3}$ Agribusiness Department, Faculty of Agriculture, Universitas Bengkulu, Bengkulu, Indonesia
}

\begin{abstract}
Indonesian smallholder oil palm plantations are facing both economic and ecological challenges, therefore the farmers struggle to be resilient. This study constructs two purposes, (1) to measure the resilience level of smallholder plantations, and (2) to assess the effect of economic and ecological disruption on smallholders' resilience. We interviewed a sample of 120 smallholders in South Bengkulu regency, Bengkulu Province, Indonesia. The methodology deploys a quantitative method (statistics and econometrics) to analyze the effect of disruptive incidents on smallholders' resilience. Resilience is indicated by farmers' ability to adapt to changes, to recover from downturn business conditions or catastrophes, to anticipate risk, and to innovate new designs of farming activities. Resilience is categorized as less or more resilient (binary). The economic disruption is triggered by production, market, and investment circumstances. Meanwhile, ecological disruption is resulted from natural disasters, climate change, farmer's treatment of the land, land fire, and government environmental policy. The result shows that more than $60 \%$ of smallholder oil palm plantations in Bengkulu Province are less resilient. Production uncertainty, bargaining position, climate change, and environmentally unfriendly farming behaviours increase the possibility of lowering smallholders' resilience level.
\end{abstract}

\section{Introduction}

In Indonesia, $38.26 \%$ of oil palm production is generated by smallholder plantations [1]. Smallholder agriculture is typically complex and heterogeneous in terms of economicecological system that is especially susceptible to perturbations. They are vital in ensuring food security in many developing countries [2]. The characteristics of this type of production system, such as small size farm ownership, low capital, labour's low productivity, traditional agriculture, price variation sensitivity [3], and limited access to

\footnotetext{
*Corresponding author: aandani@unib.ac.id
} 
information, market, and services [4], drive oil palm smallholders to be vulnerable to disruption and become less resilient. Oil palm plantation has unique features, which are seasonal, bulky, and high vulnerability to climate and market uncertainty [5]. There is also gap period between planting and harvesting time. In oil palm plantation, farmers need to wait about 4-5 years after planting to harvest first fresh fruit bunch (FFB). Smallholder agriculture is also often characterized by the incidence of poverty [6]. Under conditions, those characteristics, uncertainties, and disturbances can cause disruption and significantly degrade smallholder plantation resilience.

The concept of resilience was originally stated by Holling [7] in his research which focused on ecological systems. He tried to distinguish a condition other than stability that features a system's ability to absorb environmental changes. Farming systems are different from ecological systems in terms of production intention, environmental control and escaping environmentally induced disruptions. To build resilience in farming systems, including smallholder plantations, understanding geographical conditions, climate change, water, and other environmental circumstances is vital to note [8-10]. In previous research, resilience was measured partially. Smallholders' resilience was assessed by the adaptability capacities [11-13], the ability to recover [14-17], anticipation of risk and uncertainties [1820], and farmer's innovation level [20, 21]. This study offers comprehensive multidimensional approach to measure smallholder resilience. Smallholder resilience is conceptualized as the dynamic capacities of plantation smallholders to adapt to changes, recover from business downturn and catastrophes, anticipate risks, and innovate new designs of farming system.

The resilience of small-scale agricultural businesses, including smallholder plantations, can be conceptualized as the ability of farming systems to cope with challenges, disturbances, or even disruptions [22]. At the farm scale, resilience may be conferred by diversifying crops and livestock, and by implementing adaptive approaches in response to perturbations [23]. Resilience also refers to business ability to recover in least possible time in the case of disruptive incidents [24]. Recent trend of agricultural resilience research has shifted to economic and ecological issues. Market challenges, investment, production and input problem, climate change, natural disasters, and the urge for eco-friendly farming are the biggest challenging circumstances for recent smallholders. Thus, the most relevant agricultural disturbances for this study are economic and ecological disruptions.

Economic disruptions on agriculture arise from agricultural uncertainties, agricultural financial problems, and disorderly market conditions, including consumer behaviour. Aditya highlights three main types of uncertainties in agriculture, (1) yield/production uncertainty, (2) price uncertainty, and (3) uncertainty regarding input price and quality [25]. Price volatility becomes a major disruption for smallholder agriculture. It drives farmers to conduct adaptation farming system [26], reduce labor and input usability [27], diverse farm activities and minimize household expenditures [28], change land usage and profession [29], and vent their land ownership [30]. Hu and Rahman explained that increasing input price and decreasing output price have exerted pressure on smallholders [31]. Moreover, price volatilities, distorted market conditions, and lack of financial resources potentially have direct implications to small farms' resilience [32]. The presence of financial support increases the productivity [33], and consequently it promotes farm resilience. Conversely, the absence of this resource can harm smallholder farm's resilience.

Ecological disruptions emerge from natural calamities and ecologically unfriendly human behaviours. Earthquakes and other natural disasters have been proven as disruptive and affect farm resilience [5, 34, 35]. Climate change has impacted crop production in 
regions of smallholder dominance $[2,36]$. Smallholders' sensitivity to climate change is acknowledged by the United Nations Sustainable Development Goals (SDGs) [2], which implies that climate variabilities contribute negatively to smallholders' resilience. Beyond natural stressor, non-climatic but ecologically related destructive human behaviour in farming activities also have decreased smallholder resilience. Yang explained that common agricultural practices reduce soil productivity [37]. Soil degradation stimulates crop production decrease, which later reduces farmer's income. Land firing during land preparation for oil palm plantations is well known between farmers and companies to reduce time and cost. Unfortunately, this measure causes ecological and economic problems $[38,39]$. Another non-climatic disruption is government's ecological policies. In Indonesian oil palm industry, there is RSPO, the recent policies for sustainable palm oil [40]. For modern and developed farmers, proper application of this standard can help them produce oil palm with minimum impact on environment. Conversely, RSPO is extremely costly for small scale farmer. It stimulates increasingly sharp disparity between farmers. The impact of climatic and non-climatic disruptions on agriculture systems' resilience has been widely estimated, but comprehensive assessment of smallholders' resilience with broader dimensions (adaptability, recovery, anticipation, and innovation level) is still lacking.

Therefore, this paper aims to: (i) measure the resilience level of smallholder plantations, and (ii) assess the effects of economic and ecological disruptions on smallholder plantations' resilience. In this research, resilience is defined as the ability of smallholder plantations to ensure the provision of agricultural system function in facing the increasingly complex and accumulating economic and ecological shocks and stresses, through capacities of adaptability, recovery, anticipation, and innovation.

\section{Methods}

\subsection{Study area and data collection}

The research was conducted in South Bengkulu regency, Bengkulu Province, Indonesia. Bengkulu is one of the poorest provinces in Indonesia. More than $60 \%$ of the population are farmers, and most of them are smallholding farmers [41]. Bengkulu's economic growth is sustained by agricultural sector. Plantation commodities, including oil palm, are recognized as the major contributor. In Bengkulu Province, oil palm plant was firstly introduced in South Bengkulu regency in 1984. Nevertheless, recently, the most productive region is Mukomuko, the youngest regency in Bengkulu Province [41]. More than half of the South Bengkulu area is low to moderate plains which is considered good for oil palm growth. The green colour in figure 1 shows the area of annual crops, including oil palm, that spreads in South Bengkulu regency.

Multistage sampling technique was used to select smallholding oil palm farmers for this study. In the first stage, South Bengkulu regency was purposively chosen. Then, Pino Raya district was selected based on the largest harvest land area. In this district, two villages producing the largest oil palm were determined. The two villages are Pasar Pino and Nanjungan. In the second stage, 60 farmers were randomly selected from each village. A total of 120 farmers were interviewed using structured questionnaire. During the survey, respondents were asked to rate the current conditions and actions in retaining and expanding their business to indicate their resilience level. They were also questioned to 
assess what they feel about the disruptions. In general, this research was originally obtained from farmers' perception.

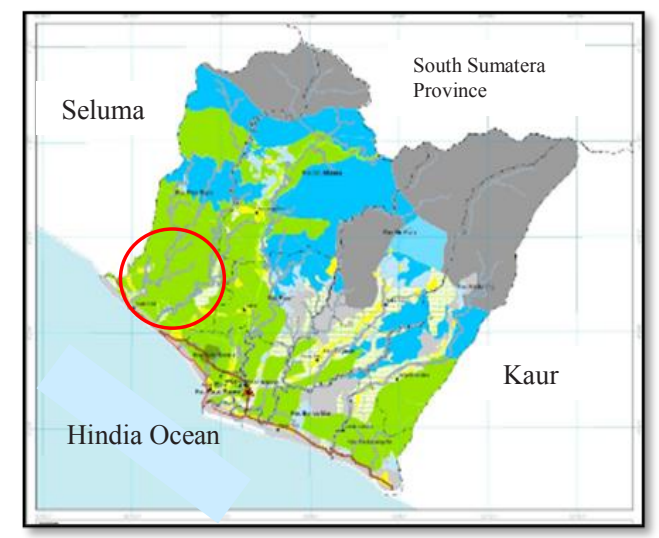

Fig. 1. Research location map

\subsection{Empirical model}

The objectives of this study are to (i) measure the resilience level of smallholder plantations, and (ii) assess the effect of economic and ecological disruption on smallholder plantations' resilience. A list of 41 items representing four dimensions of smallholder resilience (adaptability, recovery, anticipation, and innovation) was generated based on a comprehensive review of the literature [42-45]. Meanwhile, 68 items were stated in the questionnaire to represent the disruptions from economic and ecological incidents. Statements were written for each of these items (resilience or disruption) to which participants responded on a 5-point Likert-type-scale (1-strongly disagree; 2-disagree; 3neutral; 4-agree; and 5-strongly agree).

By adopting resilience measurement from Levine [17], smallholder resilience is quantified by binary model. Levine expresses that resilience can be measured by probability approach, in which resilience is analysed by probit regression model. The various measured characteristics cannot be considered as constituent of resilience, but only as predictors of its likelihood, since it certainly makes sense to describe people being more or less resilient. To measure smallholder resilience, this study used original multidimensional approach, and the formula used to calculate is:

$$
A R_{n}=\sum_{i=1}^{I} A C a p_{n}
$$

Where $A R_{n}$ is the resilience of oil palm smallholder of respondent n, $A C_{a p}$ represents total average score of each capacity dimension of respondent $\mathrm{n}$ (min. 4 point, and max. 20 point), $i$ indicates number of dimension capacity (4): capacity of adaptability, recovery, anticipation, and innovation. Then, smallholder resilience will be classified in binary, 1 for more resilient if the $A R$ score of smallholders more than mean, and 0 for less resilient if the $A R$ score of smallholders less than mean.

Based on Levine model approach of resilience analysis, and Sanchis \& Poler disruption and resilience framework [46], the estimation formula to assess the effect of economic and ecological disruption on smallholder plantations' resilience can be represented as follows:

$$
A R_{n}=E d_{1 n} \beta_{1}+E d_{2 n} \beta_{2}+\cdots+E g_{1 n} \beta_{4}+E g_{2 n} \beta_{5}+\cdots+\varepsilon_{n}
$$


Table 1. Variables and indicators description

\begin{tabular}{|c|c|c|}
\hline Variables & Measurement & Categories \\
\hline Resilience & $\begin{array}{c}\text { Binary response }(1=\text { more resilient; } 0 \\
=\text { less resilient })\end{array}$ & $\begin{array}{c}\leq \text { mean }=\text { less resilient } \\
>\text { mean }=\text { more resilient }\end{array}$ \\
\hline Adaptability & $\begin{array}{l}\text { 5-point Likert scale; represented by } 3 \\
\text { indicators: Experience towards } \\
\text { catastrophe, Diversification on } \\
\text { farming activities, and Resource } \\
\text { adaptability }\end{array}$ & $\begin{array}{c}1-1.8=\text { Not very adaptive; } \\
>1.8-2.6=\text { Less adaptive; } \\
>2.6-3.4=\text { Quite adaptive; } \\
>3.4-4.2=\text { Adaptive; }>4.2-5= \\
\text { Very adaptive }\end{array}$ \\
\hline Recovery Capacity & $\begin{array}{l}\text { 5-point Likert scale; represented by } 3 \\
\text { indicators: Willingness to recovery, } \\
\text { Pressure management, and Resource } \\
\text { maintenance }\end{array}$ & $\begin{array}{l}1-1.8=\text { Not very good; }>1.8 \\
2.6=\text { Not good; }>2.6-3.4= \\
\text { Quite good; }>3.4-4.2=\text { Good; } \\
\quad>4.2-5=\text { Very good }\end{array}$ \\
\hline Anticipation & $\begin{array}{l}\text { 5-point Likert scale; represented by } 4 \\
\text { indicators: Pre cultivation planning, } \\
\text { Crisis planning, Farming protection } \\
\text { effort, and Successor effort }\end{array}$ & $\begin{array}{c}1-1.8=\text { Not very anticipatory; } \\
>1.8-2.6=\text { Less anticipatory; } \\
>2.6-3.4=\text { Quite anticipatory; } \\
>3.4-4.2=\text { Anticipatory; }>4.2- \\
5=\text { Very anticipatory }\end{array}$ \\
\hline Innovation & $\begin{array}{l}\text { 5-point Likert scale; represented by } 3 \\
\text { indicators: Initiative, Creativity, and } \\
\text { Entrepreneurship }\end{array}$ & $\begin{array}{c}1-1.8=\text { Not very innovative; } \\
>1.8-2.6=\text { Less innovative; } \\
>2.6-3.4=\text { Quite innovative; } \\
>3.4-4.2 \text { = Innovative; }>4.2-5 \\
\quad=\text { Very innovative }\end{array}$ \\
\hline Economic Disruption & $\begin{array}{c}\text { 5-point Likert scale; indicated by } \\
\text { Production uncertainty }\left(\mathrm{Ed}_{1}\right) \text {, Input } \\
\text { availability }\left(\mathrm{Ed}_{2}\right) \text {, Price volatility } \\
\left(\mathrm{Ed}_{3}\right) \text {, Demand uncertainty }\left(\mathrm{Ed}_{4}\right) \text {, } \\
\text { Bargaining position }\left(\mathrm{Ed}_{5}\right) \text {, } \\
\text { Interest/Loan }\left(\mathrm{Ed}_{6}\right) \text {, Capital } \\
\text { limitation }\left(\mathrm{Ed}_{7}\right), \text { Consumer behaviour } \\
\left(\mathrm{Ed}_{8}\right)\end{array}$ & $\begin{array}{c}1-1.8=\text { Not very disruptive; } \\
>1.8-2.6=\text { Less disruptive; } \\
>2.6-3.4=\text { Quite disruptive; } \\
>3.4-4.2=\text { Disruptive; }>4.2-5 \\
\quad=\text { Very disruptive }\end{array}$ \\
\hline Ecological Disruption & $\begin{array}{l}\text { 5-point Likert scale; indicated by } \\
\text { Natural disaster incidents }\left(\mathrm{Eg}_{1}\right), \\
\text { Climate change }\left(\mathrm{Eg}_{2}\right) \text {, Ecologically } \\
\text { unfriendly farming activities }\left(\mathrm{Eg}_{3}\right), \\
\text { Land fire }\left(\mathrm{Eg}_{4}\right), \text { Ecological policies } \\
(\mathrm{Eg} 5)\end{array}$ & $\begin{array}{c}1-1.8=\text { Not very disruptive; } \\
>1.8-2.6=\text { Less disruptive; } \\
>2.6-3.4=\text { Quite disruptive; } \\
>3.4-4.2=\text { Disruptive; }>4.2-5 \\
\quad=\text { Very disruptive }\end{array}$ \\
\hline \multicolumn{3}{|c|}{$\begin{array}{l}\text { Since disruption is conceptualized as incidents causing damage and stimulating farmers to reduce } \\
\text { the impact, disruptive incidents which will be formulated in the econometric model are in the } \\
\text { category of more or as same as quite disruptive. The econometric model is solved by Eviews } 7 \\
\text { software. }\end{array}$} \\
\hline
\end{tabular}

\section{Results and Discussion}

\subsection{The Oil Palm Smallholders' Resilience}

Smallholders' resilience was indicated by dimensions of adaptability, recovery capacity, anticipation, and innovation level of farmers. These dimensions are reflected by a total of 13 indicators. Table 2 displays the indicator values of each resilience dimension. The results show that the largest score of resilience dimension is recovery capacity $(4.16 / 5)$. It is 
represented by farmers' willingness to recovery, pressure management capacity, and resource maintenance ability. Willingness to recovery is the most valuable indicator in this dimension. It reflects farmers' faith in God's help (4.70), family support during harmful conditions (4.70), and their ability to carry out the business (4.20). It means that the influence of significant others around farmers is extremely important to their farm sustainability. FAO highlights that under threatening circumstances farmers must be able to shortly recover to prevent disaster and food crisis [43].

Further findings show that oil palm smallholders in South Bengkulu are categorized as innovative farmers. They have very good capacity of initiative and entrepreneurship, as well as decent creativity. Initiative capacity reflects farmers' ability to make decisions quickly. This indicator also represents how farmers execute their business independently. Entrepreneurship capacity is indicated by 5 statements related with (1) farm goal/target; (2) farmers' confidence level; (3) leadership capacity; (4) farm expansion plan; and (5) ability to manage risk. Futemma explains that farmers who have innovative and entrepreneurship capacity will be able to undertake problems [23]. It implies that they are able to increase the possibility of becoming more resilient.

Table 2. Resilience level of oil palm smallholder

\begin{tabular}{|c|c|c|}
\hline Dimension of Capacity & Mean & Level \\
\hline $\begin{array}{c}\text { Adaptability } \\
\text { Experience towards catastrophe } \\
\text { Diversification on farming activities } \\
\text { Resource adaptability }\end{array}$ & $\begin{array}{l}2.58 \\
1.70 \\
3.10\end{array}$ & $\begin{array}{c}2.46 \\
\text { Less adaptive }\end{array}$ \\
\hline $\begin{array}{l}\text { Recovery capacity } \\
\text { Willingness to recovery } \\
\text { Pressure management } \\
\text { Resource maintenance }\end{array}$ & $\begin{array}{l}4.50 \\
4.10 \\
3.90\end{array}$ & $\begin{array}{l}4.16 \\
\text { Good }\end{array}$ \\
\hline $\begin{array}{c}\text { Anticipation } \\
\text { Pre cultivation planning } \\
\text { Crisis planning } \\
\text { Farming protection effort } \\
\text { Successor effort }\end{array}$ & $\begin{array}{l}3.80 \\
2.80 \\
2.00 \\
2.80\end{array}$ & $\begin{array}{c}2.85 \\
\text { Quite anticipatory }\end{array}$ \\
\hline $\begin{array}{l}\text { Innovation } \\
\text { Initiative } \\
\text { Creativity } \\
\text { Entrepreneurship }\end{array}$ & $\begin{array}{l}4.20 \\
3.50 \\
4.50\end{array}$ & $\begin{array}{c}4.07 \\
\text { Innovative }\end{array}$ \\
\hline Resilience Level & 13.75 & \\
\hline $\begin{array}{l}>13.75 \\
\leq 13.75\end{array}$ & $\begin{array}{l}38.33 \% \\
61.67 \%\end{array}$ & $\begin{array}{l}\text { More resilient } \\
\text { Less resilient }\end{array}$ \\
\hline
\end{tabular}

In general, oil palm smallholders in South Bengkulu are quite anticipatory $(2.85 / 5)$. $96 \%$ of farmers have pre-cultivation preparation and $85 \%$ of them arrange scheduled and structured planning (Table 3). Unfortunately, no oil palm farmers have farming protection scheme, like agricultural insurance. Agricultural insurance in Indonesia, as in most developing countries, is still rarely available. There are still various obstacles in the implementation of agricultural insurance in Indonesia [47]. Budhathoki et al claim that Nepal's farmers who have anticipation effort towards natural disasters have bought agricultural insurance [48]. In terms of succession of their plantations, farmers are in the 
category of quite anticipatory. $64 \%$ of farmers encourage their children to pursue the family's business, $60 \%$ of them provide their children with agricultural education, and $69 \%$ ask their children to be involved in farming activities. Meuwissen et all highlight that one of the social challenges that potentially affects farming systems is stress regarding the succession of farm [49].

The results in Table 2 also confirm that oil palm smallholders in research location are categorized as less adaptive farmers $(2.46 / 5) .73 \%$ of farmers have experienced some natural disasters, such as earthquakes, floods, droughts, and plant pests and diseases, but only $25 \%$ of farmers perform preventive actions (Table 3 ). Furthermore, more than $90 \%$ of farmers have no diversification farming activities besides oil palm plantation. Previous research formulated that there are two possible positive impacts that can be generated by smallholders in Sumatera if they allocate space for diversification [50]. First, the productivity of oil palm per unit land can be improved through plot-level diversification. The second impact stated is that diversification could furthermore assist in enhancing or maintaining environmental performance. This low-level of adaptive capacity induced smallholding farmers in Bengkulu Province to become less resilient.

Table 3. Indicator statements of oil palm smallholders

\begin{tabular}{|l|c|c|}
\hline \multirow{2}{*}{ Indicator statements } & \multicolumn{2}{c|}{ Percentage (\%) } \\
\cline { 2 - 3 } & No & Yes \\
\hline Pre cultivation preparation & 4 & 96 \\
\hline Scheduled and structured planning & 15 & 85 \\
\hline Encourage children to pursue the family's business & 36 & 64 \\
\hline Provide agricultural education background for children & 40 & 60 \\
\hline Involve children in farming activities & 31 & 69 \\
\hline Experience to natural disasters & 27 & 73 \\
\hline Perform preventive actions & 75 & 25 \\
\hline Diversification farming activities & 90 & 10 \\
\hline Prepare reserved fund & 38 & 62 \\
\hline & & \\
\hline Input price increases & 0 & 100 \\
\hline Scarcity of subsidized fertilizer & 2 & 98 \\
\hline Difficulty in finding outsource labor & 70 & 30 \\
\hline Price volatility & 11 & 89 \\
\hline Capital limitation & 56 & 44 \\
\hline Problem with interest and loan & 84 & 16 \\
\hline Natural disaster incidents impact their plantations & 35 & 65 \\
\hline Weather change & 4 & 96 \\
\hline Extreme weather & 5 & 95 \\
\hline Lack of knowledge of good agricultural practices & 25 & 75 \\
\hline Lack of information about environmental policies & 21 & 79 \\
\hline Land fire incident & 96 & 4 \\
\hline Natural disaster incidents disturbed their farm & 26 & 74 \\
\hline Need adjustment or changes duet to natural disasters & 80 & 20 \\
\hline
\end{tabular}




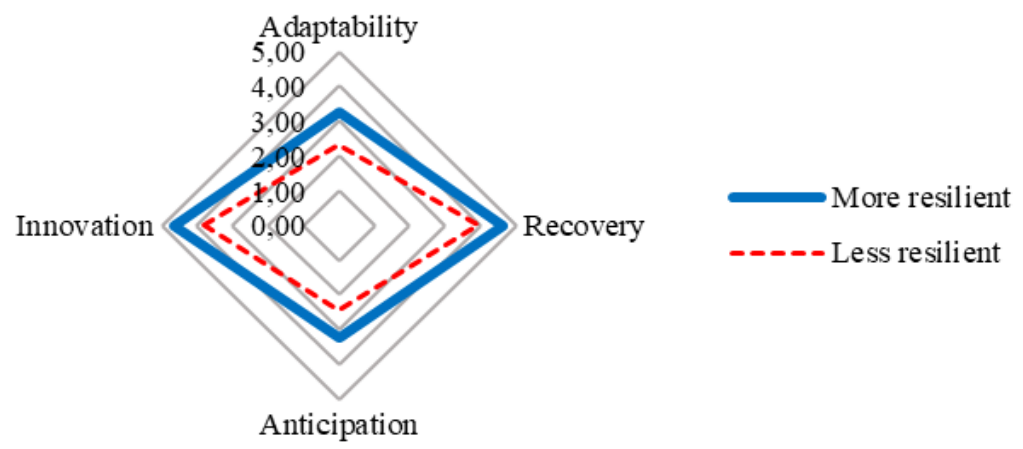

Fig. 2. Resilience's capacity of oil palm smallholders by dimension

More than $60 \%$ of farmers have under average score of resilience level and being less resilient smallholders. Figure 2 features four dimensions of smallholders' resilience between two farmers groups. More resilient smallholders have better adaptability capacity, capacity of recovery, level of anticipatory and innovation than less resilient smallholders. Resilient smallholders are categorized as quite adaptive, quite anticipatory, and innovative farmers. They also have good recovery capacity. Meanwhile, less resilient smallholders are les adaptive, less anticipatory, but quite innovative. However, they have good recovery capacity.

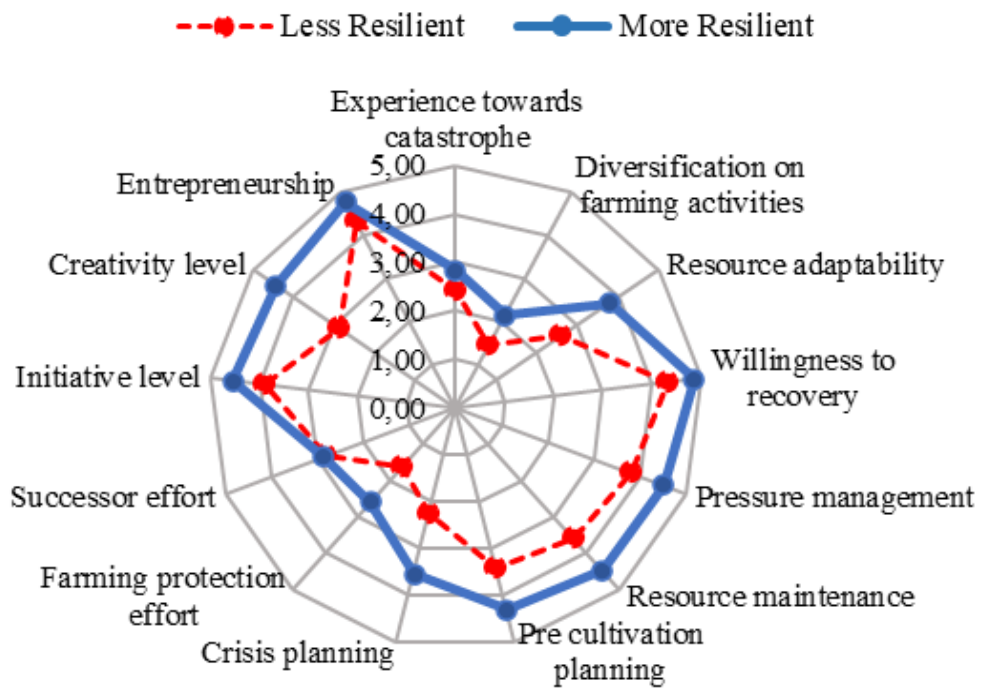

Fig. 3. Resilience of oil palm smallholders by indicators

Both groups of farmers have less capacity in handling natural disaster and diversification on farming activities (Figure 3). Resilient farmers are quite adaptive on resources adaptability, whereas less resilient farmers are not very adaptive. Only $4 \%$ of less resilient farmers have prepared organic fertilizer and seedling independently (Table 4). The most disruptive incidents related to input problems are scarcity and price increases. Conversely, there are $40 \%$ of more resilient farmers have executed those preparation independently. 
Table 4. Indicator statements by less and more resilient smallholders

\begin{tabular}{|l|c|c|}
\hline \multirow{2}{*}{\multicolumn{1}{|c|}{ Indicator statements }} & \multicolumn{2}{c|}{ Percentage (\%) } \\
\cline { 2 - 3 } & Less resilient & More resilient \\
\hline Prepare organic fertilizer and seedling independently & 4 & 40 \\
\hline Execute risk planning and alternative planning & 51 & 87 \\
\hline Agricultural insurance & 0 & 0 \\
\hline Formulate new strategy or idea & 52 & 100 \\
\hline & & \\
\hline Poor crops maintenance & 98 & 97 \\
\hline Have no power to conduct price negotiation & 100 & 48 \\
\hline Limited market information & 78 & 57 \\
\hline Increasing land tenure by big estate & 31 & 17 \\
\hline Less bargaining power disrupts smallholder & 74 & 35 \\
\hline Discontinuity of FFB acceptance by CPO factory & 65 & 22 \\
\hline FFB rejection by buyer during the transaction & 65 & 22 \\
\hline Have no problem with capital limitation & 38 & 82 \\
\hline Lack of knowledge of good agricultural practices & 85 & 58 \\
\hline
\end{tabular}

Further findings in Table 4 explore that there is a significant gap between more and less resilient farmer in crisis planning, farming protection scheme, and creativity level. $87 \%$ of more resilient farmers execute risk planning and alternative planning in anticipating crisis or disasters, but only $51 \%$ of less resilient farmers conduct these actions. There is no agricultural insurance implemented by both less and more resilient farmers, but $62 \%$ of farmers prepare reserved fund to anticipate emergency condition during cultivation. Creativity capacity reflects the ability of farmers to formulate new strategy or idea to undertake farming problem. $100 \%$ of more resilient farmers response that they have this ability. In contrast, only $52 \%$ of less resilient farmers agree that they have this creativity indicator.

\subsection{The Impacts of Economic and Ecological Disruptions on Smallholders' Resilience}

\subsubsection{Economic Disruption}

Overall, based on farmers' perspective, the economic disruptions level of oil palm plantations in Bengkulu Province are categorized as quite disruptive. From literature review, there are eight incidents that are identified as economic disruptions on oil palm plantations. Table 5 shows that the most disruptive incidents for smallholder plantations are price volatility and production uncertainty, both for less and more resilient smallholders (Figure 4). 89\% of respondents claim that the price volatility disrupts farmers' plantations (Table 3). Farmers explain that the causes of price volatility are the Covid-19 pandemic, quality of fresh fruit bunch (FFB), buyer's attitude, factory price policy, and global market condition of crude palm oil (CPO). Moreover, farmers agree that production uncertainty is mainly caused by weather changes and poor crops maintenance.

The following finding shows that farmers classify input availability as a disruptive incident towards their oil palm plantations. Even more resilient smallholders claim input problems as disruptive incidents as same as less resilient smallholders (Figure 4). The input problems exposed by farmers are price increases of oil palm seed and fertilizer $(100 \%$ of 
farmers), the scarcity of subsidized fertilizer (98\%), and the difficulty in finding labour $(30 \%)$. Less resilient smallholders $(100 \%)$ confess that they have no power to conduct price negotiations with the buyer. The problems are limited market information (78\%) and increasing land tenure by the big estate (31\%) (Table 3 ). The farmers are also interrupted by demand uncertainty. $65 \%$ of less resilient smallholders explain that there is discontinuity of FFB acceptance by CPO factory and FFB rejection by the buyer during the transaction (Table 4). The farmers figured out that the rejection was caused by the low quality of FFB (raw and rotten fruit, small size, or no kernel inside the fruit).

The most minor economic disruptions are capital limitation, consumer behaviour, and interest/loans problem. $56 \%$ of farmers confess that they have no problem with capital limitation, and $82 \%$ of more resilient farmers confirm this circumstance. Since they have less information about consumer behaviour, they explain that consumer behaviour changes are less disruptive to their oil palm plantations. The field interview also uncovers that $84 \%$ of farmers (less and more resilient) have no problem with interest and loans. They claim that they are not involved in any loan scheme because of the difficulties of meeting the loan requirement from banks or other formal finance institutions.

Table 5. Economic disruption in oil palm plantations

\begin{tabular}{|c|c|c|}
\hline Indicators & Mean & Level \\
\hline Price Volatility & 4.20 & \\
\hline Production Uncertainty & 4.01 & \\
\hline Input Availability & 3.67 & \\
\hline Bargaining Position & 3.28 & \multirow{2}{*}{$\begin{array}{c}\text { Quite disruptive } \\
(2.95)\end{array}$} \\
\hline Demand Uncertainty & 2.75 & \\
\hline Capital Limitation & 2.25 & \\
\hline Consumer Behaviour & 1.86 & \\
\hline Interest/Loan & 1.57 & \\
\hline
\end{tabular}

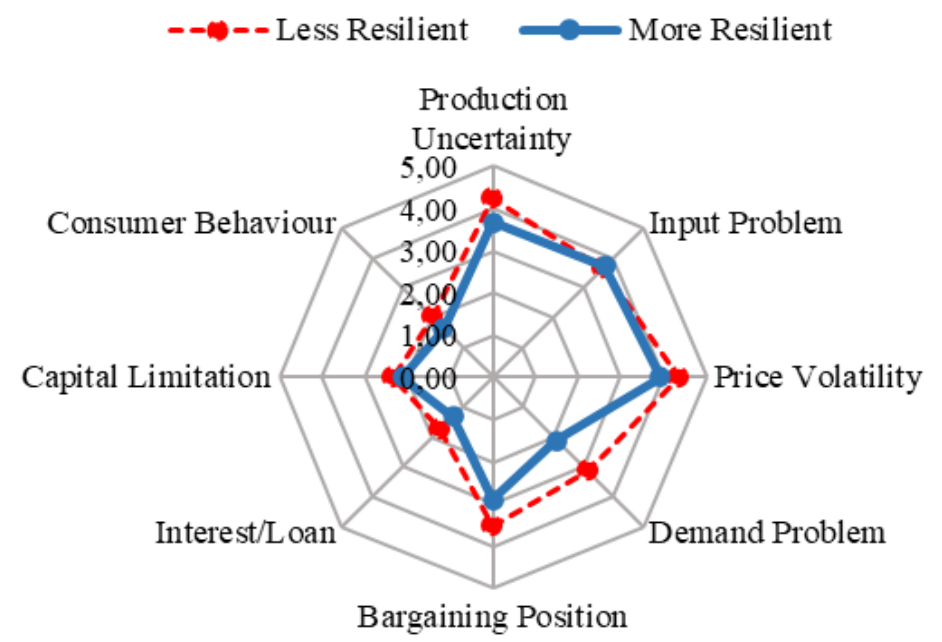

Fig. 4. Indicators of economic disruption 


\subsubsection{Ecological Disruption}

Ecological disruption is considered as an incident of intense environmental stress occurring over some time and causing significant changes in the affected ecosystem. It can result from natural causes or human activities. Table 6 shows general ecological disruption incidents in oil palm plantations. The most disruptive incident, according to farmers' perception, is climate change and categorized as disruptive. This incident is indicated by weather change conditions, heat stress claim, and the impact of this circumstance on farmers' plantations. Climate change impacts more to less resilient smallholders than their counterparts (Figure 5).

The next ecological disruption, which is classified as a quite disruptive incident, is ecologically unfriendly farming activities. Farmers (less or more resilient farmers) confess that they are in a low level of knowledge about good agricultural practices. Thus, they conduct their plantations without giving attention to the environmental impact of their farm activities. Natural disaster incidents are also in the category of quite disruptive for both classes of farmers. There are three types of disasters that are recognized by farmers. Earthquake is the most frequent natural disaster that occurred in Bengkulu Province. However, this incident causes a medium impact on oil palm plantations. Then, there are flood and drought. $65 \%$ of farmers claim that natural disaster incidents in South Bengkulu impact their plantations. They agree that the effects include crop failure, facility damage, and input distribution problem. Meanwhile, ecological policies and land fire are categorized as less disruptive by oil palm smallholders. Both less resilient and more resilient farmers confess that they lack information about environmental policies related to oil palm cultivation $(79 \%)$ and confirm that there is no land fire incident during their planting experience (96\%) (Table 3).

Table 6. Ecological disruption in oil palm plantations

\begin{tabular}{|c|c|c|}
\hline Indicators & Mean & Level \\
\hline Climate Change & 3.73 & \\
\hline Ecologically Unfriendly Farming Activities & 3.02 & \multirow{2}{*}{$\begin{array}{c}\text { Quite disruptive } \\
(2.77)\end{array}$} \\
\hline Natural Disaster Incidents & 2.97 & \\
\hline Ecological Policies & 2.09 & \\
\hline Land Fire & 2.05 & \\
\hline
\end{tabular}

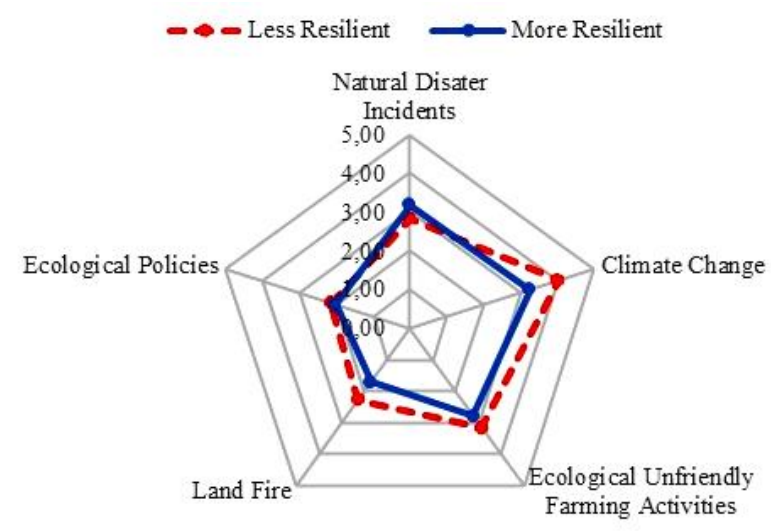

Fig. 5. Indicators of ecological disruption 


\subsubsection{How Farmers' Perspective towards Economic and Ecological Disruptions Affect Their Business' Resilience}

Probit regression model results are presented in Table 7. The goodness-of-fit tests indicate that the selected disruption determinants provide a good estimation of the probability of smallholders' resilience. The explanatory variables are jointly statistically significant (LR $x^{2}$ test $=81.3318, \mathrm{p}>0.0000)$ [51]. Coefficient estimates of the binary probit model indicate that production uncertainty has a significant negative effect $(\mathrm{p}<0.1)$ on smallholders' resilience. It explains that the increase in production uncertainty case $1 \%$ decreases the probability of oil palm smallholders' becoming more resilient about $34.74 \%$. Since they have limited resources, less resilient smallholders are forced to run low quality of cultivation, and it triggers lower oil palm productivity. 98\% of less resilient farmers agree that poor crops maintenance causes production uncertainty problem (Table 4). Meanwhile, $96 \%$ of farmers admit that unexpectedly changeable weather forces this matter (Table 3 ). Aditya uncovers that production uncertainty in agricultural business are uncontrollable [25].

Input availability shows an insignificant effect on smallholders' resilience. The case of oil palm smallholders, in research location, input availability problem is faced by almost whole farmers, such as price increasing (100\%), subsidized fertilizer (98\%), and limited labor (30\%) (Table 3). These disturbances disrupt not only less resilient smallholders, but also resilient smallholders. Smallholding farmers in less developed and developing countries face those problems frequently [3]. Consequently, most of them feature resistance attitudes and stimulate better resources adaptability capacity and become innovative farmers (Table 2).

The further findings show that all farmers face price volatility problems. Thus, this disruption indicator has an insignificant effect on smallholders' resilience. Moreover, demand uncertainty also has an insignificant impact on oil palm smallholders' resilience. Resilient farmers generally have a vast area of plants and produce more oil palm than less resilient farmers. A large amount of production on one side generates more income. Still, unfortunately, on the other side, it can be a considerable disturbance when facing the distorted markets, such as price drops and a decrease in demand. The presence of these disruptions will be more disruptive for resilient farmers than less resilient farmers.

This study considered bargaining position as a disruptive incident for oil palm smallholders' resilience. Less power of bargaining increases the probability of farmers becoming less resilient. The result shows that bargaining position status has a significant negative influence on smallholders' resilience. This finding implies that farmers with the greater problems in bargaining positions will decrease their opportunities to become more resilient. $100 \%$ of less resilient farmers express that they always agree to the FFB price decided by the wholesaler or factory (Table 4). They state that this circumstance disrupts their farm, and they need to change. $78 \%$ of them confirm that this problem was triggered by limited market information. This finding is supported by Courtois and Subervie in their research result that this type of disruption is mainly caused by limited access of smallholding farmers to information and market [52].

The ecological disruptions in this research are directed by natural disasters, climate change, and ecologically unfriendly farming activities. Frequent natural disaster incident in Bengkulu Province is the earthquake. Drought and flood are not occurring very often. These natural disasters insignificantly affect oil palm smallholders' resilience. Widely, food farming or horticultural crops are disruptive by flood or drought. Earthquake, generally, contributes disturbance in the residential area. Plantation farming, especially oil palm, is 
more resistant to these types of disasters. $74 \%$ of farmers explain that natural disaster incidents disturbed their farm, but $80 \%$ of them confess that these incidents do not need adjustment or changes in their farm activities (Table 3 ).

Climate change has been the most popular research theme in the last decade. This environmental disruption causes various agricultural failures, such as unpredictable weather, production decreases, and health issues of farmers. As expected, the result shows that climate change has a significant adverse effect on smallholders' resilience. Climate change decreases the possibility of oil palm smallholders becoming more resilient. About $95 \%$ of farmers feel extreme weather change (Table 3). They describe that in the dry season they are stressed by heat. The farmers agree that this condition also causes crops damage. They further confirm that it forces them to adapt and execute adjustments in their oil palm plantations. Heat exposure also impacts smallholding farmers' resilience in Northern Ghana [53].

The last ecological disruption which has a significant negative influence on smallholders' resilience is ecologically unfriendly farming activities. FAO explicitly reported that smallholders use chemical fertilizer more intensively than their larger counterparts [4]. Conversely, FAO also uncovered that there was a decline soil fertility and yields lowering because of lack of inputs. In the research area, $75 \%$ of farmers confess that they lack knowledge about good agricultural practices (Table 3), and 85\% of less resilient smallholders admit this problem (Table 4).

Table 7. Economic and ecological disruption impact to smallholding farmers' resilience

\begin{tabular}{|c|c|c|c|}
\hline Variables & Coefficients & Standard error & Marginal effects \\
\hline Production uncertainty & $-1.0571^{*}$ & 0.5702 & 0.3472 \\
\hline Input availability & 1.6546 & 0.5568 & 5.2364 \\
\hline Price volatility & 1.3554 & 0.6590 & 3.8815 \\
\hline Demand uncertainty & 0.0065 & 0.2431 & 1.0066 \\
\hline Bargaining position & $-0.6126^{*}$ & 0.3513 & 0.5417 \\
\hline Natural disaster incidents & 0.5746 & 0.2042 & 1.7770 \\
\hline Climate change & $-1.2755^{* * *}$ & 0.4361 & 0.2791 \\
\hline Ecologically unfriendly farming activities & $-0.9533^{* * *}$ & 0.3945 & 0.3852 \\
\hline Constanta & -0.0212 & 2.5506 & \\
\hline LR $x^{2}$ & & 69.6326 \\
\hline p-value & \multicolumn{3}{|l}{} \\
\hline Number of observations & & 0.0000 \\
\hline
\end{tabular}

$* * *, * *$, and $*$ confirm that it is statistically significant at $1 \%, 5 \%$, and $10 \%$, respectively.

\section{Conclusions and Policy Implications}

This study uses a multidimensional approach to resilience measurement based on a comprehensive review of literature. The resilience of smallholder oil palm farmers was measured by farmer's perception about how they adapt to environmental changes, recover from downturn business conditions or catastrophes, anticipate risk, and innovate new design of farming activities. The smallholding plantation farmers have a very good level of willingness to recovery, good pressure management, and resources maintenance in 
representing their recovery capacity level. They also feature innovative farmers by having a very good initiation and entrepreneurship character, and a good level of creativity. This research also uncovered that the smallholders have the quite anticipatory ability. This dimension was enlightened by pre cultivation planning, crisis planning, farming protection, and successor effort. Meanwhile, the adaptability capacity of smallholders was indicated as less adaptive. They are less adaptive on experience towards catastrophe, not very adaptive on farming activities diversification, and quite adaptive on resource adaptability. Estimation results confirmed that economic disruptions indicated by production uncertainty and bargaining position significantly weaken oil palm smallholders' resilience. Furthermore, the ecological disruptions represented by climate change and ecologically unfriendly farming activities also significantly negatively affect the resilience of smallholder oil palm plantations in Bengkulu Province.

The findings of this research have important policy implications. The production uncertainty could be the consequence of poor plant maintenance and climate problems existence. Whereas the bargaining position was more likely caused by limited access of farmers to information and market. The stable condition of the country on politics and economic environment and providing accessible market information from the government could help smallholder plantations reinforce their resilience. This study also highlights how climate change and farming habits contributed to weakening the smallholders' resilience. Thus, providing climate information and strengthening the adaptability of farmers to this disruption can assist farmers to enhance their resilience level. Moreover, to reduce the habit of ecological unfriendly farming activities, the government should intensively provide more extension and training programs about good agricultural practices.

Acknowledgment: Funding for this research was provided by The Ministry of Education, Culture, Research and Technology of The Republic of Indonesia, and supported by Indonesia Endowment Fund for Education (LPDP). The authors are immensely thankful to the farmers for providing valuable information needed during the field surveys.

\section{References}

1. BPS, Statistics Indonesia (BPS, 2019)

2. P. Lamichhane, K.K. Miller, M. Hadjikakou and B.A. Bryan, Sci. Tot. Env. 719, 1 (2020)

3. FAO, Part one: Smallholders and Their Characteristics (2020)

4. G. Rapsomanikis, The Economic Lives of Smallholder Farmers (2015)

5. Z. Guido, C. Knudson, T. Finan, M. Madajewicz and K. Rhiney, World Dev. 132, 1 (2020)

6. P.R. Brown, S. Afroz, L. Chialue, T. Chiranjeevi, S. El, C.M. Grunbuhel, I. Khan, C. Pitkin, R. Reddy, C.H. Roth, S. Sacklokham, L.J. Williams, Clim. Dev. 11, 383 (2019)

7. C.S. Holling, Ann. Rev. of Ecol. And Sys. 4, 1 (1973)

8. A. Bonfante, A. Impagliazzo, N. Fiorentino, G. Langella, M. Mori and M. Fagnano, Sci. Tot. Env. 601-602, 603 (2017)

9. S.H. Brunner and A.G. Regamey, Env. Sci. \& Pol. 66, 129 (2016) 
10. S. W. Bunting, N. Kundu and N. Ahmed, Oce. \& Coa. Man. 148, 63 (2017)

11. J. Borrell, S. Dodsworth, F. Forest, O. Pérez-Escobar, M. Lee, E. Mattana, P. Stevenson, M.J. Howes, H. Pritchard, D. Ballesteros, B. Kusumoto, I. Ondo, J. Moat, W. Milliken, P. Ryan, T. Ulian, S. Pironon, Env. And Exp. Bot. 170, 1 (2020)

12. L. Peng, J. Tan, W. Deng and Y. Liu, Int. J. of Env. R. and Pub. Hea. 17, 1 (2020)

13. J. Vargas and D. González, Int. J. of Saf. And Sec. Eng. 6, 282 (2016)

14. J. Wreathall, Developing Models for Measuring Resilience, (2006)

15. Y.Y. Haimes, K. Crowther and B.M. Horowitz, Sys. Eng. 11, 287 (2008)

16. E. Ortas, J.M. Moneva, R. Burritt and J. Tingey-Holyoak, Bus. Eth. 297 (2013)

17. S. Levine, Humanitarian Policy Group ODI, (2014)

18. I.S.M. Sin, N.A. Musa and K.Y.N. Ng, Glo. Bus. \& Fin. Rev. 22, 38 (2017)

19. J. Panerati, N. Schwind, S. Zeltner, K. Inoue and G. Beltrame, P. O. 13, 1 (2018)

20. Department for Environment, F. \& Rur. Aff. 24, 7 (2013)

21. C. Futemma, F.D. Castro and E.S. Brondizio, Lan. Use. Pol. 99, 1 (2020)

22. C. Folke, Ecol. And Soc., 21, 1 (2016)

23. J. M. Bullock, K.L. Dhanjal-Adams, A. Milne, T.H. Oliver, L.C. Todman, A.P. Whitmore and R.F. Pywell, J. of Ecol., 105, 880 (2017)

24. O. Erol, B. Sauser and M. Mansouri, Ent. Inf. Sys. 4, 111 (2010)

25. H. Aditya, Uncertainty in Agriculture: 4 Types (2020)

26. T. Nicod, B. Bathfield, A. Promkhambut, K. Duangta and B. Chambon, Agr. Sys. 182, 1 (2020)

27. A. Pareed and M. Kumaran, J. of Aca. R. in Econ. 9, 293 (2017)

28. N. Karunakaran, J. of Kri. Vig., 5, 160 (2017)

29. C. Kubitza, V.V. Krishna, Z. Alamsyah and M. Qaim, Hum. Ecol. 46, 107 (2018)

30. T. Vongvisouk and M. Dwyer, Falling Rubber Prices in Northern Laos: Local Responses and Policy Options (Helvetas, 2016)

31. Z. Hu and S. Rahman, Sing. J. of Tro. Geo. 36, 324 (2015)

32. M. Czekaj, A.A. Fiskovica, E. Tyran and E. Kilis, Glo. F. Sec. 26, 1 (2020)

33. G. Wirakusuma and I. Irham, IConARD 2020 (E3S, 2021)

34. M. Ferreira, F. Mota de Sa and C. Oliveira, Bul. Ear. Eng. 9, 1 (2015)

35. R. Roy, A.K. Gain, N. Samat, M. Hurlbert, M.L. Tan and N.W. Chan, Ecol. Indi. 106, 1 (2019)

36. S. Eissler, B.C. Thiede and J. Strube, Glo. Env. Cha. 57, 1 (2019)

37.Z. Yang, S. Chen, X. Liu, D. Xiong, C. Xu, M.A. Arthur, R.L. McCulley, S. Shi and Y. Yang, For. Ecol. And Man. 449, 1 (2019)

38. T. Guillaume, M.M. Kotowska, D. Hertel, A. Knohl, V. Krashevska, K. Murtilaksono, S. Scheu and Y. Kuzyakov, Nat. Com. 9, 1 (2018)

39. H. Purnomo, B. Okarda, A.A. Dewayani, M. Ali, R. Achdiawan, H. Kartodihardjo and K.S. Juniwaty, For. Pol. And Econ. 91, 94 (2018) 
40. RSPO, RSPO (www.rspo.org., 2021)

41. BPS, Bengkulu Province in Figures (BPS, 2020)

42. S. Carpenter, B. Walker, J.M. Anderies and N. Abel, Ecos, 2001, 765 (2001)

43. FAO, Resilience Index Measurement and Analysis Model (FAO, 2012)

44. C. Béné, Institute of Development Studies (2013)

45. USAID, Building Resilience of Agricultural Businesses (2018)

46. R. Sanchis and R. Poler, Dir. Y Org. 54, 45 (2014)

47. R. Fadhil, M.Y. Yusuf, T.S. Bahri, H. Maulana and Fakhrurrazi, J. Hun. Univ. Nat. Sci. 48, 121 (2021)

48. N.K. Budhathoki, D. Paton, J.A. Lassa, K.K. Zander, Int. J. Dis. Ris. Red. 49, 1 (2020)

49. M.P.M. Meuwissen, P.H. Feindt, A. Spiegel, C. Termeer, E. Mathjis, Y. de Mey, R. Finger, A. Balmann, E. Wauters, J.Ag.Sy. 176, 1 (2019)

50.D. Stomph, Smallholder Oil Palm: space for diversification (Wageningen University \& Research, 2017)

51. D. Hosmer and Lemeshow, Applied Logistic Regression (John Wiley, 2020)

52. P. Courtois and J. Subervie, A.J.A.E. 97, 1 (2014)

53. K. Frimpong, S.T. Odonkor, F.A. Kuranchie and V.F. Nunfam, Heliyon. 6, 1 (2020) 